\title{
Safflower: A New Host of Cercospora beticola
}

R. T. Lartey, T. C. Caesar-TonThat, and A. J. Caesar, United States Department of Agriculture-Agricultural Research Service (USDA-ARS), Northern Plains Agricultural Research Laboratory (NPARL), Sidney, MT 59270; W. L. Shelver, USDA-ARS, Red River Valley Agricultural Research Center, Biosciences Research Laboratory, University Station, Fargo, ND 58105; N. I. Sol, USDA-ARS-NPARL; and J. W. Bergman, Eastern Agricultural Research Center, Montana State University, Sidney 59270

\section{ABSTRACT \\ Lartey, R. T., Caesar-TonThat, T. C., Caesar, A. J., Shelver, W. L., Sol, N. I., and Bergman, J. W. 2005. Safflower: A new host of Cercospora beticola. Plant Dis. 89:797-801.}

Safflower is an oilseed crop adapted to the small-grain production areas of the western Great Plains, including the Northern Plains Area (NPA). In the NPA, safflower production is being evaluated for potential rotation with sugar beet. Safflower is susceptible to Cercospora carthami, whereas sugar beet is susceptible to $C$. beticola. $C$. carthami has not been observed on safflower in the NPA but $C$. beticola is ubiquitous on sugar beet. Observation of unusual leaf spots on irrigated safflower cv. Centennial at Sidney, MT prompted this investigation of safflower as a potential alternate host of $C$. beticola. Safflower plants were inoculated with four isolates of $C$. beticola (C1, C2, Sid1, and Sid2) and incubated in growth chambers; leaf spot symptoms appeared between 3 and 4 weeks later. Polymerase chain reaction (PCR) amplification of extracts from lesion leaf tissue with $C$. beticola-specific primers produced fragments comparable with amplified fragments from purified cultures of control $C$. beticola. PCR assay of cultures of single spores from diseased safflower leaf lesions also produced fragments comparable with fragments from $C$. beticola cultures. Antibody that was raised from isolate $\mathrm{C} 2$ also bound to antigens from the single-spore cultures of the four $C$. beticola isolates. Inoculum from single-spore cultures from infected safflower also infected sugar beet and produced typical Cercospora leaf spot symptoms. Assay of these leaf lesions by PCR resulted in amplification of target fragments with the $C$. beticola-specific primers. Our results demonstrate that safflower is a new host of C. beticola.

Safflower (Carthamus tinctorius L.) is an annual, broadleaf oilseed crop adapted to the semi-arid small-grain production areas of the western Great Plains. Commercial production first was concentrated in western Nebraska and eastern Colorado, but shifted to California and the Northern Plain Area (NPA) states which include western North Dakota and eastern Montana (11).

Sugar beet (Beta vulgaris L.) is one of the most important irrigated crops in the NPA. Safflower is increasingly being evaluated for rotation with irrigated sugar beet in the NPA. Safflower and sugar beet are susceptible to Cercospora carthami Sundar and Ramakr and C. beticola Sacc., respectively. Cercospora leaf spot, caused by $C$. beticola, is one of the most important diseases of sugar beet and occurs

Corresponding author: R. T. Lartey

E-mail: rlartey@sidney.ars.usda.gov

Accepted for publication 15 April 2005.

DOI: 10.1094/PD-89-0797

This article is in the public domain and not copyrightable. It may be freely reprinted with customary crediting of the source. The American Phytopathological Society, 2005. wherever the crop is grown (3). Without control, the disease results in significant root yield loss and reduced sugar content of sugar beet roots, sugar extraction, and root storage life $(13,14)$. Gross losses can reach as much as $30 \%$ (13). The leaf spots are 3 to $5 \mathrm{~mm}$ in diameter at maturity and circular, with tan to light-brown and barkbrown to reddish-purple borders. With disease progression, the individual spots coalesce and the heavily infected leaf tissues initially turn yellow and, eventually, necrotic brown. A stroma, the sign of the pathogen, often is visible as minute black dots in the necrotic center (12).

According to Ashri (1), Cercospora leaf spot of safflower caused by $C$. carthami first was reported in India in 1924, where epidemics occurred in certain years. He cited several references that indicate that the disease has been observed only in the old world (Africa, Asia, and Europe). In the old world, the disease also has been reported specifically in Pakistan, Iran, and Israel. Symptoms are characterized by round to irregular slightly sunken brownblack spots up to $1 \mathrm{~cm}$ in diameter, with an occasional yellowing tinge at the border. Stromata of the pathogen appear as small black dots in concentric rings on diseased leaves. In severe cases, the infected leaves turn brown and distorted, followed by disintegration. The stem may blacken at the base of severely infected leaves and bending of the stem or die back may result from severe infection (Q. L. Holdeman and W. O. McCartney, personal communication). Unlike leaf blight, which is caused by Alternaria carthami Chowdhury on safflower, $(8,9) C$. carthami has not been observed previously in the NPA. Recently, Mündel and Huang (10) considered Cercospora leaf spot of safflower as mainly widespread in India and Pakistan and, therefore, did not review their control by resistant and cultural practice in the United States. On the other hand, incidence of $C$. beticola is well established in the NPA and there have been significant increased incidences of Cercospora leaf spot of sugar beet in the NPA. Thus, the observation of unusual brown necrotic spots on safflower in the NPA prompted this study of safflower as a potential host to $C$. beticola.

\section{MATERIALS AND METHODS}

Isolates and source. Four isolates $C$. beticola were evaluated. Isolates race $\mathrm{C} 1$ and C2 (18) were provided by John J. Weiland, Agricultural Research Service (ARS), Fargo, ND. Isolates Sid1 and Sid2 were isolated from infected sugar beet at Sidney, Montana by Anthony J. Caesar, ARS-Northern Plains Agricultural Research Laboratory (NPARL), Sidney, MT. Unless stated otherwise, all isolates of $C$. beticola were cultured on potato dextrose agar (PDA; Difco Laboratories, Detroit) at $25^{\circ} \mathrm{C}$ and maintained on PDA at $4^{\circ} \mathrm{C}$.

Inocula production and pathogenicity test. Mycelial were suspended in milli-Q water, spread on low-sodium V8 agar plates, and incubated at $25^{\circ} \mathrm{C}$ under constant incandescent light (15). Spores were harvested after 5 to 10 days and suspended in sterile water containing $0.1 \%$ Tween 20 . Suspensions were adjusted to $2 \times 10^{4}$ spore $/ \mathrm{ml}$ of water. Six safflower plants (cv. Centennial; 2) at the six- to eight-leafstage were spray inoculated with each of the four $C$. beticola isolates using an atomizer (Sunrise Medical HHG Inc., Somerset, PA). The inoculated plants were incubated under $90 \%$ minimum relative humidity 
(RH) and an 8 -h photoperiod at $32^{\circ} \mathrm{C}$ for 2 to 3 days. Plants then were transferred to and maintained in a growth chamber with approximately $6 \% \mathrm{RH}$ and an 8-h photoperiod at $26^{\circ} \mathrm{C}$. Untreated controls consisted of uninoculated plants which were maintained under the same conditions. The plants were observed for developments of symptoms.

Polymerase chain reaction assay for C. beticola infection in safflower. Rapid generation of polymerase chain reaction templates. A polymerase chain reaction (PCR) protocol (5) was used to examine safflower plants for infection by $C$. beticola. Templates were prepared using a modification of Extract N-Amp Plant PCR Kits (Sigma-Aldrich,. St. Louis) protocol. Leaf disks $(0.6 \mathrm{~cm}$ in diameter $)$ from uninoculated control leaves (Fig. 1A) and lesions of the infected safflower plants (Fig. 1B) were mildly homogenized in 100 $\mu \mathrm{l}$ of extraction solution and incubated at $95^{\circ} \mathrm{C}$ for $10 \mathrm{~min}$. Dilution solution $(100 \mu \mathrm{l})$ was added to the reaction, vortex mixed, and stored at $4^{\circ} \mathrm{C}$ until ready to use. Single spores also were isolated from lesions of infected safflower plants and cultured on PDA. Templates from the fungal cultures were prepared by carefully scraping the mycelia with a sterile flat spatula without disturbing the underlying agar. The mycelia then were homogenized mildly and treated as previously described for infected leaves.

PCR amplification. The $20-\mu \mathrm{l}$ PCR reaction mixture consisted of $10 \mu \mathrm{l}$ of ExtractN-Amp PCR mix (a $2 \times$ PCR reaction mix containing buffer, salts, dNTPs, Taq polymerase, and TaqStart antibody), $4 \mu \mathrm{l}$ of sample extraction solution, and $1.5 \mu \mathrm{M}$ each of the forward and reverse primers in deionized water. As described by Lartey et al. (5) the PCR reactions were primed with CBACTIN959L (5' AGCACAGTATCATGATTGGTATGG $3^{\prime}$ ) and CBACTIN959R (5' CACTGATCCAGACGGAGTACTTG $\left.3^{\prime}\right)$, which were designed to amplify an approximately 959-bp fragment of $C$. beticola actin gene sequence. In addition, the primers internal transcribed spacer (ITS) 1 (5' TCCGTAGGTGAACCTGCGG 3') and ITS4 (5' TCCTCCGCTTATTGATATGC 3') (17) also were used. A blank control (extraction solution without template) and DNA extracts from cultures of the original C. beticola isolates also were prepared. Amplification was carried out over 40 cycles using a Mastercycler gradient thermocycler (Eppendorf Scientific Inc., Westbury, NY) at $94^{\circ} \mathrm{C}$ for $1 \mathrm{~min}$ of denaturation, $52^{\circ} \mathrm{C}$ for $30 \mathrm{~s}$ of annealing, $72^{\circ} \mathrm{C}$ for 1 min of extension, and $5 \mathrm{~min}$ of final extension at $72^{\circ} \mathrm{C}$. The amplified products were resolved by electrophoresis in $1 \%$ agarose gels in Loening E buffer (6). The PCR product sizes were determined by comparing the relative mobility of the amplified fragments with the 1-kb ladder (New England BioLabs Inc., Beverly, MA) in adjacent lanes.

Enzyme-linked immunosorbent assay. As an additional proof, enzyme-linked immunosorbent assay (ELISA) was applied to demonstrate that the isolated spores from inoculated safflower lesions were $C$. beticola. The cultures of single spores of all four isolates (C1, C2, Sid1, or Sid2) from leaf lesions were harvested and subjected to ELISA using polyclonal antibodies (PAbs) raised against cell walls of the isolate $\mathrm{C} 2$ of $C$. beticola. The PAbs initially were tested for cross reactivity with Fusarium oxysporum, F. proliferatum, $F$. solani, Trichoderma harzanium, $T$. viride, T. virens, Rhizoctonia solani, Gaeumannomyces graminis var. graminis, Botrytis cinerea, and Laetisaria arvalis. The selected test fungi represent the divisions Basidiomycota, Ascomycota, and Deuteromycota and either are common in soils at the Sidney area or are being evaluated for biological control of $C$. beticola. An additional step (T. C. Caesar-TonThat, W. L. Shelver, and R. T. Lartey, unpublished) subsequently was taken to eliminate minor cross reactivity with Fusarium and Trichoderma spp. Briefly, ELISA was performed using homogenates of mycelia in carbonate buffer $(20 \mathrm{mM} \mathrm{NaHCO} 3,28$ $\mathrm{mM} \mathrm{Na} \mathrm{CO}_{3}, \mathrm{pH}$ 9.6). Homogenates were centrifuged for $10 \mathrm{~min}(14,000 \times g)$, after which $100 \mu \mathrm{l}$ of the supernatant was loaded in microplate wells (Immulon 4HBX; Dynex Technologies Inc., Chantilly, VA) followed by incubation overnight at $60^{\circ} \mathrm{C}$. After washings with $0.01 \mathrm{M}$ phosphate buffer saline-Tween 20, 0.138 $\mathrm{M} \mathrm{NaCl}, 2.7 \mathrm{mM} \mathrm{KCl}, \mathrm{pH} 7.4$ (PBST; Sigma-Aldrich), $100 \mu \mathrm{l}$ of a 1/1,000 dilution of the third boost rabbit serum was added to each well. Microplates were incubated for $90 \mathrm{~min}$ at $22^{\circ} \mathrm{C}$, washed with PBST, then further incubated for $60 \mathrm{~min}$ at

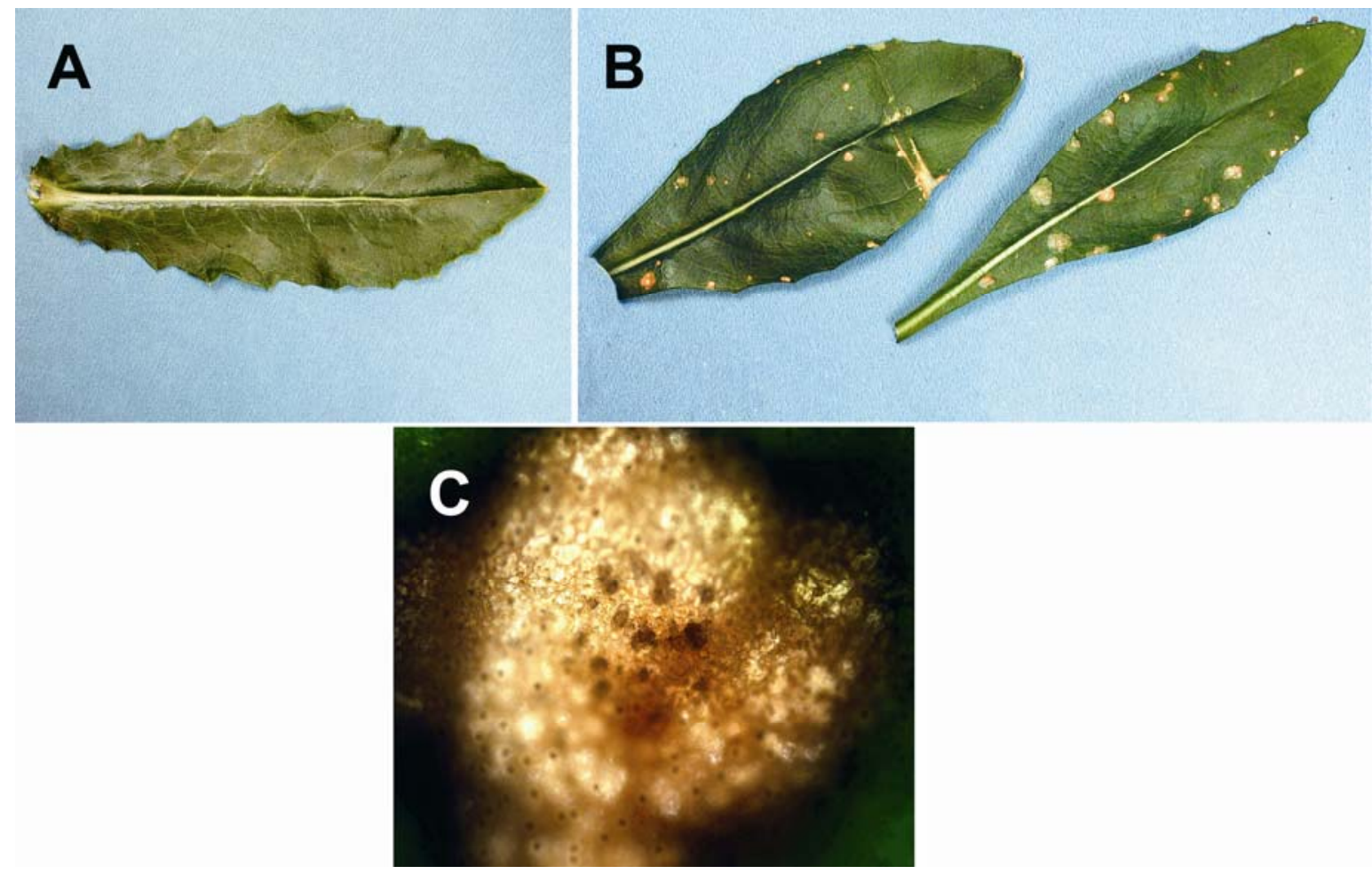

Fig. 1. A, Healthy safflower leaf and B, Cercospora beticola (C2)-infected safflower leaves. Lesions are characterized by light-brown round to irregular spots. The dark-brown to black border is noticeable around some of the disease lesions which were positively shown to contain $C$. beticola. $\mathbf{C}$, Fructifications in leaf spot caused by $C$. beticola (C2) in safflower. 
$22^{\circ} \mathrm{C}$ with a $1 / 10,000$ dilution of horseradish peroxidase-conjugated goat anti-rabbit immunoglobulins (Sigma-Aldrich) added to each well. After PBST washings, the substrate, consisting of a solution of $3,3^{\prime}$, $5,5^{\prime}$ tetramethylbenzidine $(0.4 \mathrm{~g} /$ liter $)$ (Pierce, Rockford, Illinois) and $0.02 \%$ hydrogen peroxide, was added. Absorbance was read at 450 or $655 \mathrm{~nm}$ using a BioRad 550 microplate reader (BioRad, Hercules, CA). All incubation steps were performed at room temperature. All samples were processed in triplicate.

Isolation from safflower, infection, and assay of sugar beet for $C$. beticola. Safflower leaves showing spot symptoms were incubated on wet paper towels in a closed plastic container at $25^{\circ} \mathrm{C}$ overnight. The spores then were carefully removed with sterile sharp glass tips and transferred to PDA. The cultures were maintained as previously described. Mycelial suspension from the colonies next were transferred to V8 agar to produce spores as previously described. The spores then were used to spray inoculate sugar beet plants as previously described for safflower. The plants were maintained initially under high humidity and then transferred to a growth chamber as described for safflower. Control plants were not inoculated. All plants were observed over a period of 6 weeks for development of symptoms.

After symptoms had developed, the infected sugar beet plants were assayed for infection of $C$. beticola by PCR. From the treated sugar beet plants, leaf discs $(0.6$ $\mathrm{cm})$ were removed from the spot lesions as described for safflower. Templates were prepared and subjected to rapid detection by PCR using the previously described protocol. Controls consisted of uninoculated sugar beet plants and DNA extracts from cultures of original $C$. beticola isolates. All pf the above experiments were repeated at least once.

\section{RESULTS}

Between 2 and 3 weeks after inoculation, the first leaf spot symptoms were observed on the safflower plants inoculated with each of the four $C$. beticola isolates (Fig. 1B). The symptoms appeared as round to irregular light-brown to black spots, frequently with dark-brown to black borders. With the aid of a dissecting scope or microscope at a low magnification $(\times 10)$, dark-brown to black fructifications of the pathogen could be observed in some of the leaf spot lesions (Fig. 1C). The uninfected control safflower plants did not develop the leaf spot symptoms (Fig. 1A).

PCR assay for $C$. beticola in safflower symptom tissues. The results of the PCRbased detection of $C$. beticola in infected safflower tissues is presented in Figure 2A. Expected fragments of all the $C$. beticola isolates (C1, Sid1, C2, and Sid 2) were amplified by the $C$. beticola actin-specific primers CBACTIN959L and CBAC-

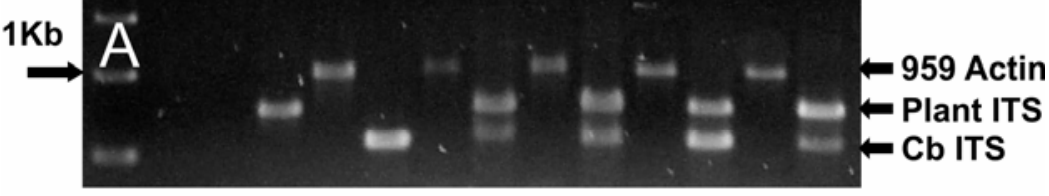

$\begin{array}{lllllllllllll}1 & 2 & 3 & 4 & 5 & 6 & 7 & 8 & 9 & 10 & 11 & 1213 & 14\end{array}$

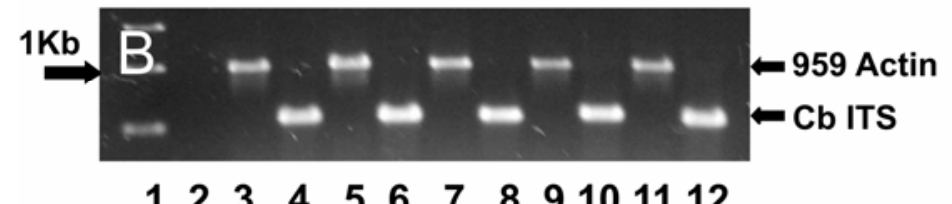

$\begin{array}{llllllllllll}1 & 2 & 4 & 5 & 6 & 7 & 8 & 9 & 1011 & 12\end{array}$

Fig. 2. Detection of Cercospora beticola in infected safflower by polymerase chain reaction. A, Direct detection by amplification of $C$. beticola segments from lesion leaf tissues with actin-specific (lanes 3,5 , 7, 9, 11 and 13) and internal transcribed spacer (ITS; lanes 4, 6, 8, 10, 12, and 14) primers. Lane $1=1-\mathrm{kb}$ ladder; $2=$ blank control; 3 and $4=$ uninfected safflower control; 5 and $6=$ Sid 1 control culture; 7 and $8=$ $\mathrm{C} 1$ from infected leaf lesion; 9 and $10=$ Sid 1 from infected leaf lesion; 11 and $12=\mathrm{C} 2$ from infected leaf lesion; 13 and $14=$ Sid 2 from infected leaf lesion. B, Detection by amplification of $C$. beticola segments from cultures of single spore isolates from diseased safflower leaf lesions with actin-specific (lanes $3,5,7$, 9 , and 11) and ITS (lanes 4, 6, 8, 10, and 12) primers. Lane $1=1-\mathrm{kb}$ ladder; $2=$ blank control; 3 and $4=$ Sid1 control from genomic DNA extract; 5 and $6=\mathrm{C} 1$ from infected leaf lesion; 7 and $8=$ Sid1 from infected leaf lesion; 9 and $10=\mathrm{C} 2$ from infected leaf lesion; 11 and $12=\mathrm{Sid} 2$ from infected leaf lesion.

Table 1. Detection of Cercospora beticola in safflower leaves using an enzyme-linked immunosorbent assay (ELISA) ${ }^{\mathrm{a}}$

\begin{tabular}{lccccc}
\hline & & \multicolumn{4}{c}{ Absorbance at 450 m$^{\mathbf{b}}$} \\
\cline { 3 - 6 } Weight $^{\mathbf{c}}$ & Stock $^{\mathbf{d}}$ & $\mathbf{C 2}$ & Sid2 & C1 & Sid1 \\
\hline $100 \mu \mathrm{g} / \mathrm{ml}$ & 0.530 & 0.388 & 0.536 & 0.161 & 0.240 \\
$50 \mu \mathrm{g} / \mathrm{ml}$ & 0.337 & 0.307 & 0.472 & 0.112 & 0.163 \\
$25 \mu \mathrm{g} / \mathrm{ml}$ & 0.265 & 0.240 & 0.395 & 0.082 & 0.123 \\
$10 \mu \mathrm{g} / \mathrm{ml}$ & 0.153 & $\ldots$ & $\ldots$ & $\ldots$ & $\ldots$ \\
$1.5 \mu \mathrm{g} / \mathrm{ml}$ & 0.059 & $\ldots$ & $\ldots$ & $\ldots$ & $\ldots$ \\
$380 \mathrm{ng} / \mathrm{ml}$ & 0.040 & $\ldots$ & $\ldots$ & $\ldots$ & $\ldots$ \\
PBS control & 0.008 & $\ldots$ & $\ldots$ & $\ldots$ & $\ldots$
\end{tabular}

a Fungi grown in potato dextrose agar, freeze dried, sonicated for $30 \mathrm{~s}$, and dilutions made in carbonate buffer.

b Absorbance values were means of three adjacent wells. All absorbance values were from the same ELISA plate. $C$. beticola preparations of mycelial culture were from spores of C1, C2, Sid1, or Sid2 isolated from lesions of inoculated safflower leaves; $\ldots=$ not tested.

c Mycelial dry weight. PBS = phosphate-buffered saline, 0.01 M, pH 7.4.

${ }^{\mathrm{d}}$ C. beticola $\mathrm{C} 2$ preparations of mycelium from stock culture.

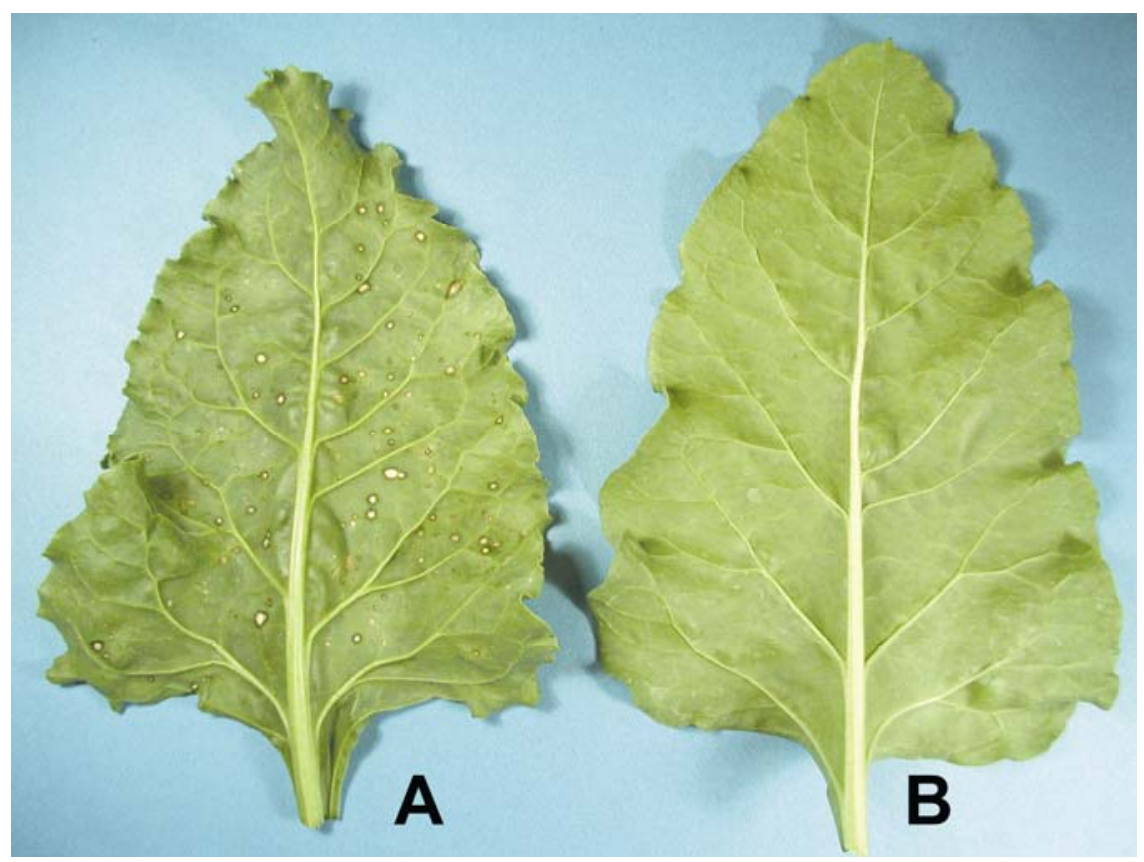

Fig. 3. A, Sugar beet infected with Cercospora beticola (C2) from previously infected safflower. B, Healthy sugar beet leaf. 
TIN959R (Fig. 2A; lanes 7, 9, 11, and 13 respectively). The amplified 959-bp fragments correspond to the positive control of DNA extract from Sid1 pure culture (Fig. 2A; lane 5). Using the ITS primers, fragments of about $0.6 \mathrm{kbp}$ also were amplified from leaf lesions caused by all the four the C. beticola isolates (Fig. 2A; lanes 8, 10, 12, and 14). The fragments correspond in size with the fragment from the Sid1 positive control culture (Fig. 2A; lane 6). Additional ITS fragments of about $0.7 \mathrm{kbp}$ also were amplified from infected lesions and these correspond to amplified ITS fragments from the uninoculated control safflower plant (Fig. 2A; lane 4). No amplification was observed in the blank control (Fig. 2A; lane 2) and the uninfected control safflower sample by the 959 actin primers (Fig. 2A; lane 3).

PCR assay of cultures from single spores. The single spores which were isolated from the four $C$. beticola isolates produced colonies on PDA which were characteristic of $C$. beticola (data not shown). The PCR results mirrored those of the direct detection of $C$. beticola from the lesions of infected safflower (Fig. 2A). The blank control (Fig. 2A; lane 2) did not produce any amplified fragment. The purified genomic DNA from the Sid1 isolate produced single 959-bp actin and ITS fragments (Fig. 2A; lanes 3 and 4, respectively). All the expected fragments of all the tested of $C$. beticola isolates $(\mathrm{C} 1, \mathrm{Sid} 1$, $\mathrm{C} 2$, and $\mathrm{Sid} 2$ ) were amplified by the CBACTIN959L and CBACTIN959R primers (Fig. 2A; lanes 5, 7, 9, and 11, respectively). The amplified fragments correspond to the positive control fragment. Using the ITS primers, fragments from all the $C$. beticola isolates also were amplified from cultures of single spores isolated from infected lesions (Fig. 2B; lanes 6, 8, 10, and 12). However, unlike direct amplification from the safflower lesions, no additional ITS fragments were observed.

ELISA for the detection of $C$. beticola in safflower. Of the fungi from different genera tested, $F$. oxysporum, $F$. proliferatum, F. solani, T. harzanium, T. viride, and $T$. virens, mildly reacted to our ELISA system (data not shown). To eliminate the unknown antibodies present in serum which cross reacted with the Fusarium and
Trichoderma spp. antigens, serum was mixed with pure mycelia followed by high-speed centrifugation (T. C. CaesarTonThat, W. L. Shelver, and R. T. Lartey, unpublished). The application of this method diminished the cross reactivity and decreased the absorbance values close to background readings in ELISA tests (data not shown).

By using ELISA of mycelial preparations of $C$. beticola (isolate $\mathrm{C} 2$ ), the fungus was detected at levels as low as $380 \mathrm{ng} / \mathrm{ml}$. Preparations of mycelia cultured from spores of C1, C2, Sid1, or Sid2 isolated from lesions of inoculated safflower leaves were reactive in ELISA tests; however, mycelia cultured from spores of $\mathrm{C} 2$ and $\mathrm{Sid} 2$ were more reactive than $\mathrm{C} 1$ and Sid1 (Table 1).

Isolation from safflower, infection, and assay of sugar beet for $\boldsymbol{C}$. beticola. All the sugar beet plants inoculated with inoculum from single-spore cultures of the four isolates which were reisolated from inoculated safflower lesions produced leaf spot symptoms. The first symptoms appeared about 2 weeks after inoculation and were characteristic of Cercospora leaf spot of sugar beet (Fig. 3B). The control plants did not develop leaf spot symptoms (Fig. 3B).

After development of symptoms, the infected sugar beet leaf lesions were examined directly by PCR for presence of $C$. beticola. The results of the PCR assay for $C$. beticola in the sugar beet lesions tissues are presented in Figure 4. Expected fragments of all the $C$. beticola isolates $(\mathrm{C} 1$, Sid1 C2, and Sid 2) were amplified using C. beticola actin primers CBACTIN959L and CBACTIN959R (Fig. 4; lanes 7, 9, 11, and 13 , respectively). The amplified fragments were about $1 \mathrm{~kb}$ and correspond to the amplified fragment from the control $C$. beticola (Fig. 4; lane 5). However, no amplification by the actin primers was observed in the control uninfected sugar beet (Fig. 4; lane 3). Using the ITS primers, fragments of the $C$. beticola isolates also were amplified from the infected lesions (Fig. 4; lanes 8, 10, 12, and 14). These fragments correspond to the ITS from the positive $C$. beticola control (Fig. 4; lane 6). Additional ITS fragments also were amplified from lesions. These correspond to ITS fragments from the uninfected negative control sugar beet (Fig. 4; lane 4). The

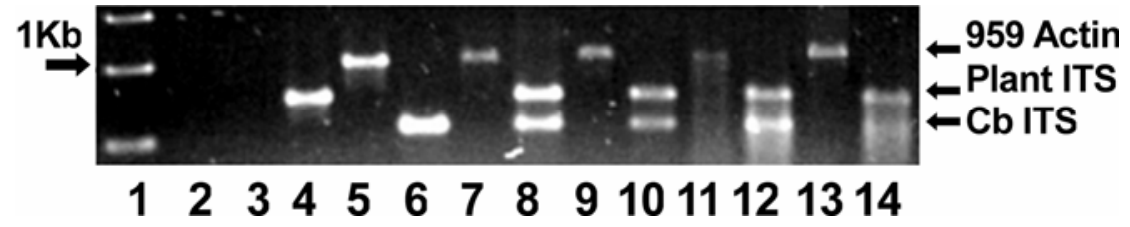

Fig. 4. Detection of Cercospora beticola in infected sugar beet by polymerase chain reaction with actin-specific (lanes 3, 5, 7, 9, and 11) and internal transcribed spacer (ITS; lanes 4, 6, 8, 10, and 12) primers. Lane $1=1-\mathrm{kb}$ ladder; $2=$ blank control; 3 and $4=$ uninfected sugar beet control; 5 and $6=$ Sid 1 control culture; 7 and $8=\mathrm{C} 1$ from infected leaf lesion; 9 and $10=$ Sid 1 from infected leaf lesion; 11 and $12=\mathrm{C} 2$ from infected leaf lesion; 13 and $14=$ Sid 2 from infected leaf lesion. double fragments indicate amplification of host plant ITS in addition to that of the pathogen. The manufacturer's control blank (Fig. 4; lane 2) produced no amplifications.

\section{DISCUSSION}

This study presents evidence that safflower is a new host of $C$. beticola, the causal agent of Cercospora leaf spot of sugar beet. All four tested isolates of $C$. beticola produced leaf spot symptoms in safflower. We demonstrated the presence of $C$. beticola in the leaf spot lesions of safflower by PCR and culture of single spores from the lesions. Inocula of all four C. beticola isolates, which were produced from single-spore cultures and reisolated from leaf lesions of diseased safflower, caused typical Cercospora leaf spot symptoms in sugar beet plants. Assay of the sugar beet lesions using the PCR technique also demonstrated the presence of $C$. beticola in the sugar beet lesions. As further proof of presence of $C$. beticola spores in the lesions of the infected safflower plants, we subjected cultures of single spores of all four isolates from safflower lesions to an ELISA test. Our test results were consistent with our PCR assay and offered additional proof of the presence of $C$. beticola in the safflower lesions which were induced by inoculation with $C$. beticola. Thus, we were able to show that $C$. beticola can infect safflower under greenhouse conditions and that inoculum from infected safflower also can infect sugar beet.

Both safflower and sugar beet have been reported to be infected by two different species of Cercospora, C. carthami and $C$. beticola, respectively. In addition to sugar beet, $C$. beticola causes leaf spot lesions on most Beta spp., such as red garden beets, Swiss chard, and mangel-wurzel (7). Several weeds were described by Vestal (16) as susceptible to $C$. beticola. This list includes Chenopodium album L., Amaranthus retroflexus L., Malva rotundifolia L., Plantago major L., Arctium lappa L., and Lactuca sativa $L$. In recent years, other common weeds such as mallow, bindweed, (19), winged pigweed, wild buckwheat, and common unicorn flower (4) have been named as hosts of Cercospora beticola. However, infection of sugar beet by $C$. carthami or safflower by $C$. beticola has never been previously demonstrated.

To our knowledge, this is the first demonstration of infection by $C$. beticola of safflower, a species of Carthamus, and of the family Asteraceae. It is interesting to note that the observed disease in safflower was not as severe as in sugar beet under our experimental conditions. However, that does not exclude or reduce the likelihood of movement of $C$. beticola inoculum between the two crops under field conditions. Our studies, which present evidence of safflower as a new host of C. beticola, demonstrate a need for caution in rotation 
between irrigated safflower and sugar beet. Measures should be taken to reduce movement of inoculum between the two crops.

\section{LITERATURE CITED}

1. Ashri, A. 1971. Evaluation of the world collection of safflower, Carthamus tinctorius L. I. Reaction to several diseases and association with morphological characters in Israel. Crop Sci. 11:253-257.

2. Bergman, J. W., Riveland, N. R., Flynn, C. R., Carson, G. R., and Wichman, D. M. 2001. Registration of 'Centennial' safflower. Crop Sci. 41:1639-1640.

3. Bleiholder, H., and Weltzien, H. C. 1972. Beiträge zür Epidemiologie von Cercospora beticola Sacc. an Zuckerrübe: Geopathologische Untersuchungen. Phytopathol. Z. 73:93114.

4. Jacobsen, B. J., Collins, D., Zidack, N., Eckhoff, J., and Bergman, J. 2000. Management of Cercospora leaf spot in western North Dakota and eastern Montana. Sugarbeet Res. Ext. Rep. 30.

5. Lartey, R. T., Weiland, J. J., Caesar-TonThat, T., and Bucklin-Comiskey, S. 2003. A PCR protocol for rapid detection of Cercospora beticola in infected sugar beet tissues. J. Sugar Beet Res. 40:1-10.
6. Loening, U. E. 1969. The determination of the molecular weight of ribonucleic acid by polyacrylamide gel-electrophoresis. Biochem. J. 113:131-138.

7. McKay, M. B., and Pool, V. W. 1918. Field studies of Cercospora beticola. Phytopathology. 8:119-136.

8. Mortensen, K., and Bergman, J. W. 1983. Cultural variance of Alternaria carthami isolates and their virulence on safflower. Plant Dis. 67:1191-1194.

9. Mortensen, K., Bergman, J. W., and Burns, E. E. 1983. Importance of Alternaria carthami and A. alternata in causing leaf spot diseases in safflower. Plant Dis. 67:1187-1190.

10. Mündel, H.-H., and Huang, H. C. 2003. Control of major diseases of safflower by breeding for resistance and using cultural practices. Pages 293-310 in: Advances in Plant Disease Management. H. C. Huang and S. N. Acharya, eds. Research Signpost, Trivandrum, India.

11. Oelke, E. A., Oplinger, E. S., Teynor, T. M., Putnam, D. H., Doll, J. D., Kelling, K. A., Durgan, B. R., and Noetzel, D. M. 1992. Safflower. University of Wisconsin Coop. Ext. Serv., Center Alternative Plant Animal Products, University of Minnesota Ext. Serv., St. Paul, MN. Online.

12. Ruppel, E. G. 1986. Cercospora leaf spot. Pages 8-9 in: Compendium of Beet Diseases and Insects. E. D. Whitney and J. E. Duffus, eds. American Phytopathological Society, St. Paul, MN.

13. Shane, W. W., and Teng, P. S. 1992. Impact of Cercospora leaf spot on root weight, sugar yield and purity of Beta vulgaris. Plant Dis. 76:812-820.

14. Smith, G. A., and Ruppel, E. G. 1971. Cercospora leaf spot as a predisposing factor in storage rot of sugar beet roots. Phytopathology 61:1485-1487.

15. Tuite, J. 1969. Plant Pathological Methods, Fungi and Bacteria. Burgess Publishing Company, Minneapolis, MN.

16. Vestal, E. F. 1933. Pathogenicity, host response and control of Cercospora leaf spot of sugar beet. Agric. Exp. Stn. Iowa State Coll. Agric. Mechanics Arts Res. Bull. 168.

17. Weiland, J. J., and Sundsbak, J. L. 2000. Differentiation and detection of sugar beet fungal pathogens using PCR amplification of actin coding sequences and the ITS region of the rRNA gene. Plant Dis. 84:475-482.

18. Whitney, E. D., and Lewellen, R. T. 1976. Identification and distribution of races of $\mathrm{C} 1$ and $\mathrm{C} 2$ of Cercospora beticola from sugar beet. Phytopathology 66:1158-1160.

19. Windels, C. E., Lamey, A. H., Hilde, H., Widner, J., and Knudsen, T. 1998. A Cercospora leaf spot model for sugar beet, in practice by an industry. Plant Dis. 82:716-725.

\section{Erratum}

A correction was made to this article on August 12, 2005. The image for Figure 4 was incorrect. 